О. Л. Чумак

\title{
МОВНА АГРЕСІЯ В ЕПІСТОЛЯРНОМУ ТЕКСТІ ГРИГОРІЯ ГУСЕЙНОВА
}

Чумак О. Л. Мовна агресія в епістолярному тексті Григорія Гусейнова.

У статті розглянуто мовну агресію в епістолярному тексті роману у щоденниках і листах «Повернення в Портленд» Г. Гусейнова. Акцентовано на тому, що проблема агресії $є$ частиною емоційного досвіду письменника, його внутрішнього стану. Досліджено лексико-семантичні особливості мовної агресії. Проаналізовано дефініцію агресія у словниках. Визначено лексико-семантичні

(с) О. Л. Чумак, 2018. 
групи слів мовної агресії. Репрезентовано шари лексики зі значенням мовної агресії.

Ключові слова: агресія, мовна агресія, дефініція, форми вираження мовної агресіï. Гусейнова.

Чумак Е. Л. Языковая агрессия $\quad$ в эпистолярном тексте Григория

В статье рассматривается языковая агрессия в эпистолярном тексте романа в дневниках и письмах «Возвращение в Портленд» Г. Гусейнова. Акцентируется внимание на том, что проблема агрессии является частью эмоционального опыта писателя, его внутреннего состояния. Исследуются лексико-семантические особенности языковой агрессии. Анализируется дефиниция агрессии в словарях. Выделяются лексико-семантические группы слов языковой агрессии. Репрезентируются пласты лексики со значением языковой агрессии.

Ключевые слова: агрессия, языковая агрессия, дефиниция, формы выражения языковой агрессии.

Chumak O. L. Speech aggression in a epistolary text by Grygori Guseinov.

Modern stage of linguistic progress is recognized by its increased focusing on the studies of speech aggression. Specialists in psychology, sociology, and politology take specific interest in the analysis of aggression. Linguists haves started studying aggression as a phenomenon of linguistic communication since latter half of the twentieth century. Topicality of the speech aggression investigation results from the increase in social aggression being observed in the community. Category of aggression is scantily studied problem in the context of modern linguistics; thus, objective of the paper is to determine speech aggression in terms of current Ukrainian language with the help of epistolary materials. A novel in diaries and letters "Back to Portland" by Grygori Guseinov is taken for the analysis. To achieve the objective, following problems should be solved: aggression in linguistic dictionaries; and lexical and semantical of words representing the category of speech aggression.

Category of aggression holds a special place in the novel by Grygori Guseinov. Thus, his works are very important for the studies. A problem of aggression is a part of emotional experience of the writer and his internality. Hence, it is possible to consider a state of mean-spiritedness, unkindness, and aggression as lexis of a word aggression representing emotional state. Originality, novelty, and individual style of the writer are manifested in his unique mystification basing upon his fabulated chronicles. As an integral component of human consciousness, language records elements of the aggression category within definitions of defining dictionaries. Analysis of lexis of a category of aggression makes it possible to say that the majority of the lexis emotionally coloured and represented with the help of various lexical layers. In terms of 
factual selection of materials, the category of speech aggression is explained by means of different lexemes, i.e. aggression words expressed with the help of nouns, verbs, adjectives; moreover, lexical and semantical groups have been singled out.

Determination of groups of speech aggression is an important part of the studies; it involves further studies of the lexis of semantics of aggression. Future studies will concern comparative analysis of lexical and semantical structure of the category of speech aggression.

Key words: aggression, speech aggression, definition of forms of speech aggression expression.

Сучасний етап розвитку мовознавства відзначається підвищеною увагою до вивчення мовної агресії. Найбільшу зацікавленість у дослідженні агресивності виявляють психологи, соціологи, політологи. Мовознавці почали досліджувати агресивність як явище мовної комунікації 3 другої половини ХX століття. Актуальність вивчення мовної агресії зумовлена наростанням суспільної агресії, яка спостерігається в суспільстві.

До мовних виявів, пов'язаних з агресивністю зверталися як вітчизняні, так і зарубіжні вчені, а саме: Р. Берон, О. Бикова, О. Власова, Т. Воронцова, В. Желвіс, Л. Закоян, Дж. Річардсон, Ю. Щербініна та ін. У дослідженні О. Власової йдеться про те, що «мовна агресія в різних сферах життєдіяльності людини має багато функцій. Основні 3 них: 1) засіб впливу на адресата; 2) засіб нанесення психологічної шкоди; 3) засіб вираження влади та мовного насилля» [2, с. 113].

О. Демидов потрактовує агресію як фізичні та вербальні дії, що передбачають такі компоненти, як атака, напад, ворожнеча, загроза. Окрім того, складовим елементом агресії є мовне насилля. Мова, по суті, вплітається в насилля та агресію і стає знаряддям тиску. Мовна агресія, на думку вченого, пов'язана 3 негативною оцінкою того чи того явища або особи $[4$, с. 7$]$.

Агресивність $є$ малодослідженою ділянкою в сучасній лінгвістиці, тому метою запропонованої статті $є$ визначення ролі мовної агресії в сучасній українській мові на епістолярному тексті (роман у щоденниках і листах «Повернення в Портленд» Григорія 
Гусейнова). Досягнення цієї мети потребує розв'язання таких завдань: 1) репрезентувати дефініцію поняття «агресія» в лінгвістичних словниках; 2) здійснити лексико-семантичний аналіз слів, що репрезентують категорію мовної агресії.

Насамперед визначимо значення поняття «агресія». Слово «агресія» походить від латинського aggressio, що в перекладі означає «напад, захоплення території» [6, с. 12]. У наш час термін «агресія» отримав широке потрактування. У «Великому тлумачному словнику сучасної української мови» агресія тлумачиться як «неспровокований збройний напад однієї держави на іншу з метою загарбання iї території, ліквідації або обмеження іiі незалежності» $[1$, c. 18]. У словнику іншомовних слів агресія визначається як «незаконне, 3 погляду міжнародного права застосування сили одним господарством проти другого, особливо озброєного нападу на інше господарство задля захоплення його території, ліквідації незалежності, зміну політичного або соціального укладу тощо» [6, с. 12]. Синонімічний ряд категорії агресивності представлено словами напад, агресія, наліт, наскок, набіг, наӥзд [7, с. 36].

У лінгвістичних розвідках поняття «агресія» ще не одержало однозначного тлумачення. Поняття «мовна агресія», «мовленнєва агресія», «вербальна агресія», «словесна агресія», «комунікативна агресія», «мова ворожнечі», а ще «мова ворожості», «словесного екстремізму», «дискурс ненависті й ворожості» широко вживається як у вітчизняній, так і в зарубіжній науковій літературі останніх десятиріч. Ці поняття майже стали термінологічними. Агресія, інструментом якої є не сила, а слово - це мовна агресія. Проблема вербальної агресії знаходиться у сфері компетенції психолінгвістики.

Твори Григорія Гусейнова становлять важливий об'єкт дослідження. Оригінальність, індивідуальний стиль письменника передає авторську думку, що репрезентована в епістолярному тексті. Епістолярне мовлення у своєму типовому вияві монологічне, проте природними елементами епістолярного тексту 
можуть стати, на думку П. Дудика, «і діалоги, почуті або прочитані автором, а потім відтворені в листі» [5, с. 97]. Ознаками епістолярного тексту, як стверджує мовознавець, $є$ те, що «в його основі матеріали 3 власного життя, 3 власної думки, 3 власного чуття, конкретно суттєве описання дійсності» [5, с. 97]. Недослідженою залишається в епістолярному тексті Г. Гусейнова мовна агресія, що посилює й увиразнює лексико-семантичну структуру, деталізує індивідуальний стиль, манеру опису письменника. У романі в щоденниках і листах мовна агресія виявляється через авторські негативні емоції, викликані певними подіями або людьми, які його оточують, що безпосередньо впливає на зміст тексту та формує своєрідну думку про певні події, суспільні явища, людей.

Результати дослідження роману у щоденниках і листах дають змогу виокремити такі лексико-семантичні групи слів мовної агресії:

- лексема війна асоціюється 3 агресією, тому що війна $\epsilon$ результатом озброєної боротьби між державами або окремими лідерами і викликає почуття страху за своє життя в людини. Негативні асоціації викликають лексеми, пов'язані 3 війною та військовою справою: изе так жорстоко киянам мстив Бабин Яр, щзо у війну став місцем масових розстрілів (3, с. 55); у війну в будинку окупанти розмістили гестапо (3, с. 60); крок ліворуч, крок праворуч - розстріл (3, с. 136); багатотисячна сила татарського війська полилася стрімко вниз, знищуючи на шляху все живе (3, с. 166); розповідають, що в громадянську й Вітчизняну там відбувалися розстріли (3, с. 189);

- іменники, що репрезентують агресію: ще довго в столичному культурному середовищі пахло скандалом (3, с. 21); часом буває мордобій (3, с. 33); Клава усміхається, $і$ я бачу, що в очах у неї сльози. Садизм (3, с. 81); однак розумію, щзо конфлікт насправді в іншому (3, с. 104); люди, юначе, діляться на травоїдних та хижаків (3, с. 116); викрили кубло шпигунства й 
тероризму (3, с. 140); і в мене вистачило нахабства (3, с. 151); ввечері на розбори приходили товарознавці, але морди бити не стали (3, с. 153); натяку на ускладнення $i$ потенційні побойща (3, с. 162); іменники - найменування суб'єктів агресї: гурт шибайголів у Жулянах (3, с. 116); Георгій Коваль розпочав свої пошуки з колишнього бандита Круподері (3, с. 133); виріс мікрорайон, відбудували трампарк, на залишках дамби-вбивиі висадили тополі (3, с. 56); іменники, що репрезентують знаряддя агресії: а вже звідти винесла сплющений шматочок металу. Це була куля-вбивця, щчо ї̈ згодом випадково віднайшла вдова Софія Миронівна (3, с. 132); гарячі чоловіки висмикували зі штанів ремені з великими блискучими бляхами, швидко їх намотували на руку й грізно підступали до очманілого беззахисного баяніста (3, с. 168); іменники - образи-символи 3 Біблії, що асоціюються 3 агресією: пекло розділясться на три частини - ближча, дальша та пекло самотності (3, с. 155); напевно, я все ж таки закінчений хуліган, й за ије мені доведеться колись смажитися в пеклі (3, с. 189);

- дієслова фізичної або психічної дії, напрямки яких семантично пов'язані з агресією: учитель обзивав нас безрукими $i$ примушував після уроку вимітати за собою з майстерні стружки (3, с. 8); хлопия жорстоко били (3, с. 154); він став погрожувати» (3, с. 167); уб'ють гармоніста (3, с. 168); дієслова агресивного емоційного стану: хоча мати лаялася (3, с. 73); Вона злилася (3, с. 81); на кого всмерть ображався, випліскував злість (3, с. 103); відповідав нахабно (3, с. 104); суворо допитав якогось старого чоловіка (3, с. 133); знову будемо щзоденно ненавидіти (3, с. 18);

- прикметники, що позначають риси характеру людини: суворий учитель (3, с. 8); став ще агресивнішим (3, с. 95); бачив перед собою лише набурмосену жорстоку Руду (3, с. 136); маю страшенно сварливий характер (3, с. 140); прикметники, що описують природу, події та асоціюються 3 агресією: навколо такою мірою все вбивче ци принизливе (3, с. 158); сувора осінь поступово звужує географію мандрувань (3, с. 163); листування - 
страшна річ (3, с. 291); прикметники, що передають кольорову гаму та асоціюються 3 агресивним настроєм і відношенням письменника до описуваного: прощай назавжди, бридке й ніяке Городище (3, с. 138); усе виглядало тяжким $i$ гнітючим, хоч вішайся (3, с. 138); у Києві тепер жодних яскравих фарб, крім сумних - чорного, сірого й гнилувато-жовтого (3, с. 143); настрій гидотний (3, с. 169).

Мовна агресія прямо пов'язана $з$ інвективною лексикою, яка представлена в романі такими прикладами: Теж фраєрюга! (3, с. 81); лаяв себе як останню наволоч (3, с. 138); може, сам я такий ідіот? (3, с. 140); але таки паскудник ией Еміль Дімітров (3, с. 200); хотілося їм в очі сказати: дурні! (3, с. 201).

До складників, що передають мовну агресію в тексті щоденників i листів Г. Гусейнова, посилюють семантичну структуру належать фразеологічні одиниці: кожного з нас зайли, наче блошиці, свої нагальні турботи (3, с. 26); життя дістає в тім'ячко, і я дуже скоро почну вити вовком (3, с. 41); та й вовчі закони зовсім не такі всесильні (3, с. 141); насправді час лиме завити вовком (3, с. 156); однак купатися ніхто не припинив, а навіть хтось із хлопиів забрав кілька черепів (вовків боятися - в ліс не ходити) з собою додому (3, с. 170).

Досліджувана лексика мовної агресії представлена такими шарами: нейтральна лексика, що репрезентує фізичну або психічну діяльність, називає суб'єктів агресії; експресивна, емоційно-забарвлена лексика; розмовна та просторічна лексика, а також інвективна лексика. Проблема агресії $\epsilon$ частиною емоційного досвіду письменника, його внутрішнього стану, тому уможливлює зарахування до відповідної лексики слова, що репрезентують емоційний стан - стан злості, жорстокості, агресивності.

Отже, мова як невід'ємний компонент свідомості людини фіксує елементи структури категорії агресії в дефініціях тлумачних словників. Аналіз лексики мовної агресії дає змогу 
стверджувати, що більшість цієї лексики є емоційно забарвленою, репрезентована різними шарами. У тексті Г. Гусейнова мовна агресія маніфестується найрізноманітнішими лексемами, відмінними i в семантичному, i в граматичному, i y функціональному аспектах. Ідеться передовсім про такі слова мовної агресії, як іменники, дієслова, прикметники. Диференціація груп мовної агресії $є$ важливою частиною вивчення матеріалу та передбачає грунтовне дослідження лексики семантики агресії. Перспективу подальшого дослідження становить зіставне вивчення лексико-семантичної структури категорії мовної агресії.

\section{Література}

1. Великий тлумачний словник сучасної української мови / [уклад. і голов. ред. В. Т. Бусел]. -К. ; Ірпінь : ВТФ «Перун», 2004. - 518 с.

2. Власова Е. В. Пресса третьего рейха как пространство проявления речевой агрессии / Е. В. Власова // Речевая агрессия в современной культуре : сб. науч. тр. - Челябинск : ЧГУ, 2005.- С. 113-118.

3. Гусейнов Г. Повернення в Портленд : роман у щоденниках і листах / Г. Гусейнов. - К. : Ярославів Вал, 2011. - 368 с.

4. Демидов О. В. Проявление речевой агрессии в юридическом дискурсе: практика лингвистических экспертиз / О.В. Демидов // Речевая агрессия в современной культуре : сб. науч. тр. - Челябинск : ЧГУ, 2005. - С. 7-14.

5. Дудик П. С. Стилістика української мови : [навчальний посібник]. - К. : ВЦ «Академія», 2005. - $368 \mathrm{c}$.

6. Словник іншомовних слів / Уклад. : С. М. Морозов, Л. М. Шкарапута. - К. : Наукова думка, 2000. - 680 с.

7. Словник синонімів української мови : у 2-х т. / А. А. Бурячок, Г. М. Гнатюк, С. І. Головащук та ін. - К. : Наукова думка, 1999-2000. - 567 с.

Стаття надійшла до редакиї 07.11.2017 p. 